\title{
First record of Tyrophagus putrescentiae (Schrank) (Acari: Acaridae) in soybean plants under no tillage in Minas Gerais, Brazil
}

\author{
Primeiro registro de Tyrophagus putrescentiae (Schrank) (Acari: Acaridae) em plantas de soja \\ sob plantio direto em Minas Gerais, Brasil
}

\section{Charles Martins de Oliveira ${ }^{\mathrm{I}}$ Denise Návia ${ }^{\mathrm{II}}$ Marina Regina Frizzas ${ }^{\mathrm{II}}$}

\begin{abstract}
Tyrophagus putrescentiae (Schrank) is a mite species of economic and medical-veterinary importance, usually found associated with stored products. Presence of this mite was observed in the stems of soybean [Glycine max (L.) Merr.] plants originated from a under non tillage commercial crop in 2003/2004, in the municipal district of Unaí, State of Minas Gerais, Brazil. This is the first record of T. putrescentiae occurring in soybean plants under field conditions in the world.
\end{abstract}

Key words: mite, Glycine max, Astigmata, South America.

\section{RESUMO}

Tyrophagus putrescentiae (Schrank) é uma espécie de ácaro de importância econômica e médico-veterinária, comumente encontrada associada a produtos armazenados. A presença desse ácaro foi constatada no interior de hastes de plantas de soja [Glycine max (L.) Merr.] sob plantio direto provenientes de um plantio comercial no município de Unaí, Estado de Minas Gerais, Brasil, na safra 2003/2004. Este é o primeiro registro de $\mathbf{T}$. putrescentiae em plantas de soja, em condições de campo, no mundo.

Palavras-chave: ácaro, Glycine max, Astigmata, América do Sul.

Tyrophagus putrescentiae (Schrank) (Acari: Acaridae) is one of the main mite species present in several stored products causing economic losses due to the reduction on the nutritional value of grains and the germinative power of seeds, besides the dissemination of fungi and bacteria (KRANTZ, 1955; HUGHES, 1976; HUBERT et al., 2003).

In the 2003/2004 harvest in the county of Unaí/MG, soybean plants [Glycine $\max$ (L.) Merr.] cv. Monsoy 800182 days after sowing under no-tillage system presented staining at the roots crown, few roots, leaves with mosaic aspect and posterior wilting and death of the plant. These symptoms were observed in irregular patch in all cultivated area. Samples obtained from roots and from the aerial part of these plants were sent to the Laboratory of Phytopathology, Embrapa Cerrados, for a possible isolation of phytopathogenic agents (bacteria and/or fungi) without, however, revealing the presence of none of these agents. An expressive number of mites in longitudinal vegetation were observed inside the stems of plants. These mites were colleted, fixed in $70 \%$ alcohol, preserved in microscopy slide in Hoyer medium and then identified by Dr. Barry M. O’Connor, from the Zoology Museum of the University of Michigan (USA) as belonging to the $\boldsymbol{T}$. putrescentiae species.

Although widely known as pests in storage conditions, several Tyrophagus species have been observed in crops, infesting and causing damage in the aerial part of plants, for example $\boldsymbol{T}$. neiswanderi Johnston \& Bruce in solanaceous in Switzerland

\footnotetext{
IEmbrapa Cerrados, Rod. BR 020 km 18 (Brasília/Fortaleza), CP 08223, 73310-970, Planaltina, DF, Brasil. E-mail: charles@cpac.embrapa.br. Autor para correspondência.

IIEmbrapa Recursos Genéticos e Biotecnologia, Pq. Estação Biológica, Final W5 Norte, CP 02372, 70770-900, Brasília, DF, Brasil.

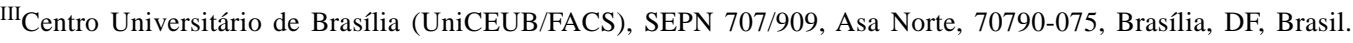


(FISCHER, 1993), in orchids in New Zealand (MARTIN \& WORKMAN, 1988) and in flowers in Japan (EHARA \& GOTOH, 2000); T. similis Volgin in melon seeds in Italy (LAFFI, 1980); T. dimidiatus (Hermann) in spinach in the USA (LANGE \& BACON, 1958); T. longior (Gervais) in ornamental plants in England (BUXTON, 1989); T. similis, T. perniciosus Zachvatkin and T. putrescentiae in cucurbitaceous and solanaceous in Japan (EHARA \& GOTOH, 2000).

In Brazil, T. putrescentiae has been reported infesting stored products and fungi culture mediums and insect diets in laboratory (FLECHTMANN, 1986; FRANZOLIN \& BAGGIO, 2000). This mite was also found in pineapple crops in the state of Bahia, but presented no relevance as pest (SANCHES \& FLECHTMANN, 1982)

It is possible that the damages observed in soybean plants have been caused by primary $\boldsymbol{T}$. putrescentiae infestation, as observed for several species from the same genus, or that the mite infestation is secondary, with plant colonization occurring after the attack of some other organism, once several mite species are opportunistic and invade vegetal tissues or stored products based on the primary attack of other arthropods, fungi or bacteria.

The occurrence of $\mathbf{T}$. putrescentiae in field suggests the possibility that seeds previously infected might have been the source of the field infestation. It is also possible that this species could be transported to the grain storage site during harvest, where mite populations would find favorable temperature and humidity conditions for their development, especially in the period from December to April (FRANZOLIN \& BAGGIO, 2000).

The no-tillage system promotes the accumulation of organic matter and the increase on the relative humidity in the microregion close to the soil (SALTON \& MIELNICZUK 1995; COSTA et al., 2004). These factors may contribute for the increase on $\mathbf{T}$. putrescentiae populations that would infest soybean plants. This is the first record of T. putrescentiae occurring in soybean plants under field conditions in the world.

\section{ACKNOWLEDGMENTS}

To Pedro Henrique de Macedo Bernardes Jr. (Coagri - Unaí, MG) by collection and sent of soybean samples, to Dra. Maria José Davila Charchar (Embrapa Cerrados, Planaltina, DF) by phytopathological analysis and to Dr. Barry M. O’Connor (Museum of Zoology, University of Michigan, USA) by the taxonomic identification of mites.

\section{REFERENCES}

BUXTON, J.H. Tyrophagus longior (Gervais) (Acarina: Acaridae) as a pest of ornamentals grown under protection. Plant Pathology, v.38, n.3, p.447-448, 1989.

COSTA, F.S. et al. Aumento de matéria orgânica num latossolo bruno em plantio direto. Ciência Rural, v.34, n.2, p.587589, 2004

EHARA, S.; GOTOH, T. Colored guide to the phytophagous mites of Japan and their natural enemies. Tokyo: Nissan Chemical Industry, 2000. 110p.

FISCHER, S. Observation of a new pest of cucumber in western Switzerland, Tyrophagus neiswanderi Johnston \& Bruce (Acari: Acaridae). Revue Suisse de Viticulture, Arboriculture et Horticulture, v.25, n.2, p.103-104, 1993.

FLECHTMANN, C.H.W. Ácaros em produtos armazenados e na poeira domiciliar. Piracicaba: FEALQ, 1986. 97p.

FRANZOLIN, M.R.; BAGGIO, D. Contaminação por ácaros em arroz polido e feijão comercializados a granel. Revista de Saúde Pública, v.34, n.1, p.77-83, 2000.

HUBERT J.V. et al. Mites as selective fungal carriers in stored grain habitats. Experimental and Applied Acarology, Dordrecht, v.29, n.1/2, p.69-87, 2003.

HUGHES, A.M. The mites of stored food and houses. 2.ed. London: Technical Bulletin of the Ministry of Agriculture, Fisheries and Food, 1976. v.9, 400p.

KRANTZ, G.W. Some mites injurious to farm-stored grain. Journal of Economic Entomology, v.48, n.6, p.754-755, 1955.

LAFFI, F. Tyrophagus similis Volgin (Acarina: Acaridae): a mite injurious to melon seed-beds. Informatore Fitopatologico, v.7-8, n.1, p.17-21, 1980.

LANGE, W.H.; BACON, O.G. Crown mite damage on spinach. California Agriculture, v.12, n.1, p.9-16, 1958

MARTIN, N.A.; WORKMAN, P. The cost of integrated pest management for cymbidium orchids. In: NEW ZEALAND WEED AND PEST CONTROL CONFERENCE, 41., 1988, Palmerston North. Proceedings... Palmerston North: New Zealand Weed and Pest Control Society, 1988. 306p. p.77-80.

SALTON, J.C.; MIELNICZUK, J. Relações entre sistemas de preparo, temperatura e umidade de um podzólico vermelhoescuro de Eldorado do Sul (RS). Revista Brasileira de Ciência do Solo, v.19, n.3, p.313-319, 1995.

SANCHES, N.F.; FLECHTMANN, C.H.W. Acarofauna do abacaxizeiro na Bahia. Anais da Sociedade Entomológica do Brasil, v.11, n.1, p.147-155, 1982. 